\title{
Middle Eastern Patriarchy in Transition
}

\author{
Rania Maktabi and Brynjar Lia (guest editors) \\ University of Oslo \\ rania.maktabi@hiof.no; brynjar.lia@ikos.uio.no
}

\section{Introduction}

In Gender and Citizenship in the Middle East (2000), twenty scholars coalesced around a definition of patriarchy as a "system of social relations privileging male seniors over juniors and women, both in the private and public spheres." ${ }^{1}$ The all-woman scholarly choir presented nuanced approaches towards describing, historicizing, and analysing the contained and mediated citizenship of youth and women in contemporary states in the Middle East and North Africa (MENA) region. The editor, Suad Joseph, specified further that the privileging of male and elder rights is a constitutive characteristic of patriarchy in the region. She argued that the valorization of maleness and elders distinguishes theorization on patriarchy in a MENA context from notions of patriarchy as understood by Western feminist scholars, who "often disarticulate patriarchy and kinship." In short, MENA region scholars perceived and analysed patriarchy as a kinship-based power structure stratified along both gender and age lines.

Around a decade before that book was published, sociologist Deniz Kandiyoti pointed out in her seminal work "Bargaining with patriarchy" that patriarchy was "probably the most overused [concept], and, in some respects the most undertheorized." ${ }^{3}$ There, she perceived the autonomy of women living in Muslim majority societies, under what she termed 'classic patriarchy', as more limited and contained when contrasted to women's wider scope of action in male-dominated societies in sub-Saharan Africa. ${ }^{4}$

1 Suad Joseph, ed. Gender and Citizenship in the Middle East (Syracuse, N.Y.: Syracuse University Press, 2000), xv.

2 "Gendering Citizenship in the Middle East", in Gender and Citizenship in the Middle East, ed. Suad Joseph (Syracuse, N.Y.: Syracuse University Press, 200o), 16.

3 Deniz Kandiyoti, "Bargaining with Patriarchy", Gender and Society 2, no. 3 (1988), 274, doi:10.1177/089124388002003004.

4 Ibid., 278-81. 
Whereas the term 'patriarchy' may have been commonly applied during the heyday of the feminist movement in the 1980s, the use of the concept as a tool of analysis became gradually associated with the feminist ideological programme for women's emancipation. The use of 'patriarchy' as an analytical concept dropped to the point of becoming the 'p-word'. However, the restricted position of women and junior members of the household in societies and states that privilege male dominance has remained a topic of research, paving the way for a richer and more nuanced analysis of how patriarchy works, and the manner in which citizens and household members comply with, adapt to, resist, challenge, and rebel against patriarchal forms of authority and dominance.

\section{New Directions in the Study of Patriarchy in the Middle East}

Over the past two decades, the academic literature on patriarchy in the MENA region has focused on themes such as women's rights and state power; ${ }^{5}$ gender (in-)equality and women's position within Islamic jurisprudence, ${ }^{6}$ reform of family law; ${ }^{7}$ women's agency and empowerment; ${ }^{8}$ globalization and its impact

5 Laurie A. Brand, Women, the State, and Political Liberalization: Middle Eastern and North African Experiences (New York: Columbia University Press, 1998); Mounira Charrad, States and Women's Rights: The Making of Postcolonial Tunisia, Algeria, and Morocco (Berkeley: University of California Press, 2001).

6 Kari Vogt, Lena Larsen, and Christian Moe, eds., New Directions in Islamic Thought: Exploring Reform and Muslim Tradition (London: Tauris, 2009); Ziba Mir-Hosseini, "Muslim Women's Quest for Equality: Between Islamic Law and Feminism”, Critical Inquiry 32, no. 4 (2006), 62945, doi:10.1086/508085.

7 Annelies Moors, "Debating Islamic Family Law: Legal Texts and Social Practice", in Social History of Women and Gender in the Modern Middle East, eds. Margaret L. Meriwether and Judith E. Tucker (Boulder, Colo.: Westview Press, 1999), 141-75; Ziba Mir-Hosseini, Marriage on Trial: Islamic Family Law in Iran and Morocco (London: I.B. Tauris, 200o); Lynn Welchman, ed. Women's Rights and Islamic Family Law: Perspectives on Reform (London: Zed Books, 2004); Kenneth M. Cuno and Manisha Desai, eds., Family, Gender, and Law in a Globalizing Middle East and South Asia (Syracuse, N.Y: Syracuse University Press, 2009); Rania Maktabi, "Female Citizenship in the Middle East: Comparing Family Law Reform in Morocco, Egypt, Syria and Lebanon", Middle East Law and Governance 5, no. 3 (2013), 280-307, doi:10.1163/1876337500503003.

8 Suad Joseph and Susan Slyomovics, eds., Women and Power in the Middle East (Philadelphia, Pa.: University of Pennsylvania Press, 2001); Valentine M. Moghadam, ed. From Patriarchy to Empowerment: Women's Participation, Movements, and Rights in the Middle East, North Africa, and South Asia (Syracuse, N.Y.: Syracuse University Press, 2007). 
on women's socio-economic position; ${ }^{9}$ the transition of patriarchy due to developments such as declining fertility, changes to the family structure, legal reforms, and the expansion of education; ${ }^{10}$ gender-based violence; ${ }^{11}$ and gendered perspectives on the impact of the Arab Uprisings. ${ }^{12}$ Scholarly attention to youth politics is of more recent origin, and focuses on socio-economic conditions, the use of social media, ${ }^{13}$ and the role of youth in the Arab Spring. ${ }^{14}$

A common theme in this literature is the relative strength of the kinshipbased patriarchal social order in the MENA region, which is reflected in crossregional comparative research. For instance, in a twofold typology on gendered outcomes of revolutions in fourteen states, Valentine Moghadam differentiated between a 'woman's emancipation model' and a 'woman-in-the-family model'. While the first model granted women individual freedoms, the latter

Eleanor Abdella Doumato and Marsha Pripstein Posusney, Women and Globalization in the Arab Middle East: Gender, Economy, and Society (Boulder, Colo.: Lynne Rienner, 2003). Philippe Fargues, "Changing Hierarchies of Gender and Generation in the Arab World", in Family, Gender, and Population in the Middle East: Policies in Context, ed. Carla Makhlouf Obermeyer (Cairo: American University in Cairo Press, 1995), 179-98; Valentine M. Moghadam, "Patriarchy in Transition: Women and the Changing Family in the Middle East", Journal of Comparative Family Studies 35, no. 2 (2004), 137-62 <http://www.jstor.org/ stable/41603930>; Shereen El Feki, Sex and the Citadel: Intimate Life in a Changing Arab World (London: Chatto \& Windus, 2013).

$11 \quad$ Sara Hossain and Lynn Welchman, "Honour": Crimes, Paradigms and Violence against Women (London: Zed Books, 2005); Moha Ennaji and Fatima Sadiqi, eds., Gender and Violence in the Middle East, vol. 4, UCLA Center for Middle East Development Series (London: Routledge, 2011); Sherine Hafez, “The Revolution Shall Not Pass through Women's Bodies: Egypt, Uprising and Gender Politics", The Journal of North African Studies 19, no. 2 (2014), 172-85, doi:10.1080/13629387.2013.879710.

12 Andrea Khalil, Gender, Women and the Arab Spring (London, New York: Routledge, 2015); Nicola Christine Pratt, Maha El Said, and Lena Meari, eds., Rethinking Gender in Revolutions and Resistance: Lessons from the Arab World (London: Zed Books, 2015).

13 Navtej Dhillon and Tarik Yousef, Generation in Waiting: The Unfulfilled Promise of Young People in the Middle East (United States: Brookings Institution, 2009); Rami Khoury and Vivian Lopez, eds., "A Generation on the Move: Insights into the Conditions, Aspirations and Activism of Arab Youth: Executive Summary". Conference Report, Issam Fares Institute, American University of Beirut, $2011<$ https://www.aub.edu.lb/ifi/public_policy/arab_ youth/Documents/20111118ifi_unicef_youth_report/20120126ifi_unicef_menaro_ youth_report_agotm_english.pdf $>$; Linda Herrera, Wired Citizenship: Youth Learning and Activism in the Middle East, Wired Citizenship (New York, Abingdon: Routledge, 2014).

Michael Hoffman and Amaney Jamal, "The Youth and the Arab Spring: Cohort Differences and Similarities", Middle East Law and Governance 4, no. 1 (2012), 168-88, doi:10.1163/ 187633712X632399; Mohammad Al-Momani, "The Arab "Youth Quake": Implications on Democratization and Stability", Middle East Law and Governance 3, no. 1-2 (2011), 159-70, doi:10.1163/187633711X591521. 
predominates in Muslim majority states and embodies, according to her, "an ideological linkage between patriarchal values, nationalism and the religious order."15 Also, global survey studies suggest that patriarchal norms, rules, and practices have been particularly strong in the MENA region. Political scientists Ronald Inglehart and Pippa Norris indicated that Morocco and Egypt, two states included in their comparative study of 61 states, are at the lower ends of scales that reflect female labour participation and the degree of support for gender equality ${ }^{16}$ Along the same lines, Mary Hallward-Driemeier, Anca Bogdana Rusu, and Tazeen Hasan at the World Bank showed that legal barriers against women's autonomy and scope of action in the MENA and South Asia regions are more limited when compared to the other six world regions. ${ }^{17}$

Despite its perceived robustness, some scholars, such as demographer Phillipe Fargues and sociologist Valentine Moghadam, have argued that age and gender hierarchies in the MENA region are changing, paving the way for growing opposition to patriarchal forms of dominance. Women's educational levels are increasingly converging with those of men, and younger men are entering positions previously reserved for their elders. Fargues has noted that modernity is altering this double domination, and that resistance by the old patriarchal order is "likely to create a context of social crisis, which can be manifested by political violence." ${ }^{18}$ Similarly, Moghadam has observed that women's growing activism and increased engagement in the paid labour market, and the rise of religious orthodox forces against the expansion of women's citizenship, have exposed signs that patriarchy is in crisis. ${ }^{19}$

The perception of a crumbling patriarchal order in the MENA region is contested neither by scholars nor by policymakers. However, the degree of patriarchy's transformation, the forces that drive change, and the implications of the transformation are. As such, the Arab Uprisings which started in December

15 Valentine M. Moghadam, "Gender and Revolutions", in Theorizing Revolutions ed. John Foran (London: Routledge, 1997), 143.

16 Ronald Inglehart and Pippa Norris, Rising Tide: Gender Equality and Cultural Change around the World (Cambridge: Cambridge University Press, 2003), 5, 34, 55, 155.

Mary Hallward-Driemeier, Tazeen Hasan, and Anca Bogdana Rusu, “Women's Legal Rights over 50 Years: Progress, Stagnation or Regression?” Policy Research Working Paper, Washington, D.C. : World Bank Group, 15-16 <http://documents.worldbank.org/curated/ en/312581468338398063/Womens-legal-rights-over-5o-years-progress-stagnation-orregression>.

18 Philippe Fargues, "Changing Hierarchies of Gender and Generation in the Arab World", in Family, Gender, and Population in the Middle East: Policies in Context, ed. Carla Makhlouf Obermeyer (Cairo: American University in Cairo Press, 1995), 179.

19 Moghadam, "Patriarchy in Transition", 137. 
2010, and the variety of their trajectories and outcomes regarding similar demands for more justice, less authoritarian rule, and more inclusive forms of political participation, represent new opportunities for scholars to explore the ways patriarchal forms of dominance have been challenged and responded to by authoritarian rulers, as well as by patriarchs on the street and in homes.

Symptomatically, two Arab Human Development Reports (AHDR) which addressed societal and political challenges facing the patriarchal social order - one, in 2006, on women, ${ }^{20}$ the other, in 2016 , on youth ${ }^{21}$ - were published within a decade, with the uprisings marking a paradigmatic political juncture falling roughly between the two publications. ${ }^{22}$ Both reports used the term 'patriarchy', notably more freely in the most recent issue on youth. For instance, the 2006 AHDR report (on women) pointed out that the abiding legacy of patriarchy lies in "[m]ale control at the economic, social, cultural, legal, and political levels", which is sustained by a symbiotic relationship with state authority. ${ }^{23}$ Although the term 'patriarchy' was sparsely used, other, more elaborate terms covering its content abounded, such as "the marginalization of women", "despotic authority", "prevailing male culture", "norms sanctioning the principle of discrimination between the sexes", and "jurisprudence legislates in favor of the higher status of men." 24

In the 2016 AHDR report (on youth), the authors pointed to patterns of both continuity and change. Commenting on civic engagement, the report stated that "changes are affecting the attachment of the individual to family values and support for patriarchy." 25 It assessed that "patriarchy is still strong but gradually weakening" 26 and that "the traditional patriarchal family structure is prevalent throughout the region [...] and influences the attitudes of youth to-

20 Arab Human Development Report 2005, "Towards the Rise of Women in the Arab World", ed. United Nations Development Program (Amman: National Press, 2006) <http://www. arab-hdr.org/PreviousReports/2005/2005.aspx >.

21 Arab Human Development Report 2016, "Youth and the Prospects for Human Development in a Changing Reality", (New York: Regional Bureau for Arab States published for the United Nations Development Programme, 2016) <http://www.arab-hdr.org/PreviousReports/2016/2016.aspx>.

Nils A. Butenschøn, "Arab Citizen and the Arab State: The 'Arab Spring' as a Critical Juncture in Contemporary Arab Politics", Democracy and Security 11, no. 2 (2015), 111-28, doi:10. 1080/17419166.2015.1043078.

23 Arab Human Development Report 2005, 16.

24 Ibid., 20, 64, 90.

25 Arab Human Development Report 2016, 46.

26 Ibid., 47. 
wards gender equality."27 However, at the same time, the societal forces that sustain the patriarchal social order in the MENA region have been shaken by the mobilization of the masses, a mobilization that has been led by impoverished, dissatisfied, and marginalized youth in alliance with rebellious subcultures, nationalist and religious groups, and members of a constantly decreasing middle and lower-middle class. ${ }^{28}$

\section{Patriarchy and the Arab Spring: Liberation or Backlash?}

Perhaps the expression "shaken, but not stirred" sums up the current status of patriarchy in the MENA region. At the very least, the quotation made famous by Ian Fleming's James Bond came up in informal discussions during the collaborative effort of the eight researchers whose articles constitute this special issue of Die Welt des Islams. The texts collected in this issue spring from two panel presentations entitled "Patriarchy and the Arab Spring: Liberation or Backlash?" at the British Society for Middle Eastern Studies (BRISMES) annual meeting convened at the London School of Economics and Political Science (LSE) in London in June 2015. Most researchers were also part of The New Middle East: Emerging Political and Ideological Trends, a collaborative research project based at the University of Oslo (2011-16). ${ }^{29}$

Rather than plunging into what patriarchy 'is', this issue concentrates on what patriarchy 'does'. More precisely, the authors look into how patriarchal societal barriers are expressed, enacted, and evaded by women and youth, and how patriarchal norms are challenged and resisted in a variety of political and societal settings. Our take on patriarchy focuses on how patriarchal structures of authority based on gender and age engulf, permeate, and impact ideas and acts of individuals and groups in different states (and quasi-states) in the MENA region. In the following articles, the authors look into the specificities and subtleties of patriarchy as a structure of domination through which power and authority are stratified and distributed unequally between older and younger age cohorts - and between women and men, as well as between citizens and denizens. ${ }^{30}$ They scrutinize women's and men's agency in addressing and con-

\footnotetext{
$27 \quad$ Ibid., $5^{2}$.

28 Ibid; "A Generation on the Move"; Lina Khatib and Ellen Lust, eds., Taking to the Streets: The Transformation of Arab Activism (Baltimore: Johns Hopkins University Press, 2014).

29 For an overview of reports published as part of the NewME-project, see <http://www. hf.uio.no/ikos/english/research/projects/new-middle-east/>.

30 In this context, the term 'denizens' denotes the incomplete and mediated citizenship of female citizens, the precarious legal position of undocumented citizens, long-term
} 
fronting patriarchal norms as (female) members of Islamic movements in Israel; as politicians and party members in legislative deliberations and party politics in Morocco, Egypt, and Kuwait; as insurgents engaging in governance at the proto-state level in the name of Kurdish state-making or as part of a highly repressive totalitarian order in the name of the 'Caliphate'; and as reflected in political activism expressed through cyberspace and the Twittersphere among Sudanese youth, or through electoral mobilization of hamüla politics in northern Israel.

In his contribution, "Broken Walls: Challenges to Patriarchal Authority in the Eyes of Sudanese Social Media Actors", Albrecht Hofheinz scrutinizes the ways in which young Sudanese challenge patriarchal authority via the cybersphere. He argues that Sudanese youth are often impatient with the pace of change in their society. At the same time, they profess that new technologies have enabled them to break established norms, to expand the realm of their private sphere, and to assert their own voice. Hofheinz calls attention to the risk that such subtle sociocultural changes on the ground could go unnoticed if researchers focus mainly on the political side of the Arab Spring.

The female sphere of Islamic proselytization and public discourse in Saudi Arabia is the topic of Laila Makboul's article, "Beyond Preaching Women: Saudi $D \bar{a}$ ciya $\bar{a} t$ and Their Engagement in the Public Sphere". It demonstrates how

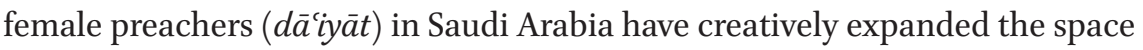
within which they engage in public discourse, legitimizing their activities with reference to the Islamic injunction on "commanding right and forbidding wrong". She shows how some dāiayat participate actively in the public discourse on issues affecting Saudi society beyond gender-specific subjects. Several factors have enabled this development, especially the viral increase in the use of social media among Saudis in general, and women in particular, and the wider educational and job opportunities for women in Saudi society. Makboul investigates, thus, how female preachers act and respond to fairly strict and orthodox interpretations of Islamic jurisprudence, skilfully adapting to norms and rules that set limits to their agency as interpreters of Islamic issues.

Female Islamist candidates for parliamentary elections are a relatively new phenomenon in the Middle East. The point of departure of Katarína Škrabákovás article, "Islamist Women as Candidates in Elections: A Comparison of the Party of Justice and Development in Morocco and the Muslim

migrants and refugees, stateless Palestinians, and the marginalized position of Kurds in contemporary states in the MENA region. Tomas Hammar, Democracy and the Nation State: Aliens, Denizens and Citizens in a World of International Migration (Aldershot: Avebury, 1990), 12-14. 
Brotherhood in Egypt", is the observation that some Islamist parties have started to promote women as candidates but that others have not. Drawing on a comparison of the recruitment of women candidates by the Party of Justice and Development (PJD) in Morocco and the Muslim Brotherhood (MB) in Egypt, she examines diverging trends in female candidacy within the two Islamist movements using what political scientists call the supply and demand model of candidate selection. Škrabáková finds that the PJD is a less centralized and more institutionalized party, and therefore better equipped to facilitate women's candidacy than the more oligarchic and secretive Egyptian мв. While useful, the supply and demand model of candidate selection is not entirely sufficient as an explanatory model, according to Škrabáková. For example, it cannot explain instances of unexpected changes in recruitment strategies based on external interference, such as the prohibition of the мв as a political movement in Egypt. Nor can it account for the impact of individual candidates' feminist credentials, that is female or male candidates' propensity to raise, or articulate, issues that expand women's autonomy through women's electoral representation. In other words, increased female representation does not necessarily translate into discourse that is more gender equal.

A relatively understudied part of the Islamist movement, namely female members of the Islamic Movement in Israel, is the topic of Tilde Rosmer's article, "Agents of Change: How Islamist Women Activists in Israel Are Challenging the Status Quo". She investigates how these women activists participate in spearheading change in their community by reshaping the ideal of the Muslim woman through educating women and men about the role and position of women in Islam. Rosmer points out that these women can be seen as Islamic feminists because they portray women's rights, gender equality, and social justice as Islamic values, engaging in rereadings of the Qur'ān and other Islamic sources to support their claims. The activism of these female Islamists also revolves around the overall goal of raising awareness about their identity as Palestinians, Arabs, and Muslims, a process which aims to empower women vis-à-vis Israeli domination. By doing so, they also respond to concerns shared by many Palestinian Israelis - men and women - who constitute what Rabinowitz has dubbed a "trapped minority". Rosmer argues that Islamist women can be seen as agents of change within a patriarchal order because they contest traditional ideals and practical roles of Muslim Palestinian women in Israel. One factor in driving this development is the experience of student life in university dormitories far from home and outside of the patriarchal organization of their community. In these university settings, opportunities are present for self-development as Muslim activists and as young, independent women. 
An historical comparison of the evolving political culture among Palestinians in the Occupied Territories with that of Palestinians inside Israel is the point of departure for Dag Tuastad's article, "Nationalist Patriarchy, Clan Democracy: How the Political Trajectories of Palestinians in Israel and the Occupied Territories Have Been Reversed." He examines the role of elections as a democratizing factor, changing patriarchal structures among the Palestinians. Tuastad contrasts the experiences of Palestinians in the West Bank and Gaza with those of Palestinians inside Israel, drawing attention to the democratizing role of holding regular political elections as a means of reducing the prevalence of patriarchal-based politics. Without elections, the authority of elders in Palestinian politics is sustained and becomes deeply entrenched, as evidenced by the very different trajectories in the evolution of political cultures in the two communities. As opposed to the Palestinians who remained inside Israel after 1948, and for whom clans remained the paramount vehicle for sociopolitical organization, the nationalist leaders of the exiled refugee communities in Gaza and the West Bank deliberately shunned and marginalized patriarchal clan-based politics. Today, although clans remain important in local Palestinian politics in Israel, a young, democratically minded generation of Palestinians has found its way into local and national politics, engaging in electoral processes, including 'tribal primaries', thereby reducing the influence of old, patriarchal leaders. By contrast, within the secular Palestinian national movement in the refugee communities, the absence of elections over the past decades has stymied political processes of renewal, rendering the political leadership increasingly gerontocratic and autocratic.

In her article, "Kurdish Women in Rojava: From Resistance to Reconstruction", Pinar Tank focuses on the case of the Kurdish Women's Protection Units (YPJ) of the Democratic Union Party (PYD), and their defence of Kurdish-dominated enclaves in north-east Syria in the aftermath of the popular uprisings which erupted in March 2011 and were followed by a civil war. She seeks to demonstrate these women's agency, and the ideologies that motivate their resistance to patriarchal representations of women's roles in the Middle East. In an effort to see beyond the traditional victim/peacemaker articulation of gendered engagement, Tank compares the agency of female Kurdish fighters to the media's portrayal of these fighters' engagement. She argues for the need to recognize the politics behind Kurdish women's participation as combatants in the Syrian civil war, and traces this engagement to the declaration of the imprisoned leader of the Kurdistan Worker's Party (PKK), Abdullah Öcalan, who, in 2010, stated that the freedom of the Kurdish people is linked to women's freedom. Öcalan's pronouncement reflects a reinvention of the PKK's ideology, one in which freedom can only be achieved through the defeat of the patriarchal 
system. PKK women thus embody, according to Tank, the organization's new ideology, which has attracted international attention due to the efforts of the Kurds to establish an autonomous region of governance in north-east Syria.

Drawing on theories of political representation, Rania Maktabi's article, "Reluctant Feminists? Islamist MPS And The Representation Of Women In $\mathrm{Ku}$ wait after 2005", seeks to explore whether and how female parliamentarians in Kuwait influenced male MPs to support female civil and economic rights after women's enfranchisement in 2005. Based on reviews of parliamentary documents between 2006 and 2016, she observes a sharp rise in the number of law proposals that addressed women's issues after the four first-ever female legislators in Kuwait were elected to the National Assembly in 2009. Maktabi suggests that Islamist MP s acted as reluctant feminists and diligent opportunists by responding to new opportunities and expectations created by the presence of female MPs. Islamist MPs, many of whom had voted against women's political rights, reformulated demands pertaining to poverty alleviation and social assistance by focusing on women as mothers, widows, and caregivers. They emphasized gender relations in ways where Kuwaiti women were seen as capacitated citizens. After the exit of female MPs from parliament in 2011, Islamist MPs stopped arguing along these lines, and their demands on behalf of women dropped sharply.

The common assumption that the jihādi movement embraces and amplifies entrenched patriarchal norms found in Arab Muslim societies is debated in Brynjar Lia's article “The Jihādī Movement and Rebel Governance: A Reassertion of a Patriarchal Order?" Although jihādī groups propagate an ideology in which gender inequality is deeply manifest, Lia argues that the social and political order established by jihādi groups in their territorial enclaves, or "protostates", is very different from traditional kinship-based patriarchy. First, jiha $\bar{a} \bar{\imath}$ proto-states are intensely ideological projects, in which blood ties and kinship play only a subordinate role. Instead, the global and non-ethnic character of the jihādī state is continuously emphasized and demonstrated, especially through prioritizing foreign fighter recruitment. These foreign volunteers are mostly young men and women with no kinship ties to the local community to which they travel, and they sever their kinship ties in defiance of their fathers (i.e. their nominal patriarchs) to join a new social, political, and ideological community. Arriving in the jihādì-ruled territory, they seek to build a community which may have some of the trappings of a patriarchal order, especially with regards to the role prescribed for women. However, on closer inspection, this utopian society is a highly regulated militarized state construct, ruled by ideological imperatives and the urgency of the military situation, not by the discretion of elder kin. 


\section{Potential Theoretical Contributions of the Articles}

There are several promising points of departure for developing a dialogue between the case studies included in this special issue and broader theoretical perspectives on expanded forms of female citizenship, on the one hand, and the growing literature on marginalized and/or mobilized youth, on the other.

First, mobilized women, retaliating youth, and supportive males - such as Islamist MPs who ideologically opposed women's political rights in Kuwait have shaken but not fundamentally uprooted patriarchal forms of authority and domination. Seen from a structural point of view, patriarchal state laws remain intact, thus sustaining women's impartial citizenship. Similarly, a patriarchal political culture has taken deep roots in the absence of regular and genuine elections, marginalizing the youth from decision-making bodies, as is demonstrated in the case of young Palestinians living in refugee camps in the West Bank and Gaza. Patriarchal laws are, moreover, hardly put in question, mainly because religious and secular groups and societal forces are willingly or unwillingly co-opted, thus helping to legitimize the status quo in countries such as Kuwait, Saudi Arabia, Morocco, Egypt, and Israel. As such, the case studies represent observations on the enduring power of the patriarchal order, particularly in states where political order was maintained after the Arab Spring.

Second, a common theme in the present articles is the waning of paternalistic forms of interaction between younger and older cohorts in the form of weakened control of elders over children, adolescent youth, and young adults who have not established an autonomous home. Waning paternalism and, by extension, weakened patriarchy and authoritarian obedience of the young towards their elders is observed in the cases of IsIs's self-declared 'Caliphate' territories, where young militants disparage and humiliate tribal elders, and also in the semi-autonomous areas of Rojava, where young Kurdish female fighters play a prominent role. In both cases, young people have been able to carve out spaces of autonomy where they assert themselves as representatives of a greater cause. In the very different contexts of Sudan and northern Israel, a somewhat similar pattern of self-assertiveness is observed when young men and women participate in everyday civic activism and resistance through the use of social media, by engaging in Islamic feminist movements, and by participating in local elections. In this sense, these articles convey features of 'everyday resistance', a term coined by historian Charles Tripp, who argues that

[w] hether the forms of resistance are violent, nonviolent, or can be classified as acts of 'rightful resistance', and whether the intention is to reform 
existing structures of power or radically reshape them, the qualities shared by much of the varied politics of resistance [...] are both intentional and demanding of public recognition. ${ }^{31}$

In short, youth and young adults who live in zones of war, as well as those who live in spaces of relative stability, have taken more control over their own lives: they are able to express themselves more freely, and are less fearful, less prone to obey and acquiesce in the wishes and preferences of their parents. Their new-found empowerment stems in no small part from the fact that, in comparison with their parents, they are far more wired into the world around them and thus more in touch with global impulses of individualization processes. Some display fierce piety coupled with disrespect of their elders, as is the case for the Isis policewomen who partake in rebel governance in Raqqa and who are obliged to beat older women for not dressing in accordance with IsIs's 'Islamic' orthodoxy.

Third, forms of patriarchal dominance and their ongoing transition are fundamentally shaped by armed conflicts and violent challenges to state power. A deep divide in the region runs between states where political order has been maintained (invariably, but not exclusively, by state coercion) and states ravaged by combinations of internal and internationalized wars (Libya, Iraq, Yemen, and Syria), in which territorial pockets of rebel governance emerge as alternatives to the incumbent regimes. Since the turn of the millennium, the global focus on combating terrorism, and the concomitant heightened securitization of international relations, have impacted the MENA region in different and unpredictable ways. Similar processes of war-making as state-building and as state-erosion - in the Middle East have long been the subject of research. These studies analyse the impact of militarized external interventions on social change following the two world wars. ${ }^{32}$ What is yet to be seen with reference to the aftermath of the (externally generated) 2003 Us-led invasion of Iraq and to the (internally induced) uprisings throughout the MENA region eight years later, is how violence on this scale has affected patriarchal social structures. One point holds true, and our collective effort in this special issue supports the following observation: wars and violent upheavals do not necessarily reinforce patriarchal trends, but they may alter the trajectory of patriarchal forces and facilitate a variety of transitional expressions, some which shore up, while others erode, forms of dominance based on age and gender.

$31 \quad$ Charles Tripp, The Power and the People: Paths of Resistance in the Middle East (Cambridge: Cambridge University Press, 2013), 9.

32 See e.g. Steven Heydemann (ed.). War, Institutions, and Social Change in the Middle East (Berkeley: University of California Press, 2000). 
Partly overlapping with the political stability versus volatile upheaval distinction (Libya being the exception), the combined observations of the authors reflect a growing political divide between maghribi and mashriqi states. In North Africa, territorial borders are more or less settled, or obliviously laid to rest by the international community (as is the case for Morocco and the Western Sahara). This has paved the way for slow and contained forms of political development, occurring in tandem with civic participation, as reflected in the cases of Morocco and the Sudan. Even in Egypt, where political development is stymied by a militarized and violently authoritarian rule, acts of resistance reminiscent of the Sudanese case are taking place, the outcome of which is yet to be seen.

By contrast, in the multireligious and multi-ethnic states of the Levant (Iraq, Syria, Palestine, and Israel), as well as in the Gulf (Saudi Arabia and Kuwait), territorial first-order issues such as consolidated borders still remain unsettled, and a demographically skewed citizenry marginalizes huge populations of non-citizens and stateless residents. Ironically, the mobilization of female citizens in the Gulf states, legitimized as a way of reinforcing the Islamic tenets of the Saudi kingdom, and by means of strengthening the civil rights of Kuwaiti women, may serve to consolidate, rather than undermine, the power of hereditary rule in both states. As such, the erosion of some parts of the patriarchal order in the two oil-rentier states may eventually "harden the core of citizenship"33 and ensure the survival of rulers in these states.

In sum, the authors of this volume detect different types of transformations of patriarchy, some of which expand and some of which contain the autonomy of women and the young. Not surprisingly, acts and deeds that have the potential to effectuate changes in patriarchal forms of dominance are more easily observed in states where political stability has been maintained than in spaces infused with violence. We conclude by stating that the MENA region is in transition: patriarchal structures are waning (but not falling), women are mobilized, and the population is getting younger and angrier. At the same time, the democracy deficit remains as acute as ever. We are probably going to witness an even greater range of political trajectories and growing cleavages between states in terms of political developments. However, in most cases, the course is set for a further erosion of the patriarchal order, driven partly by global developments in communication technology, migration patterns, and, not least, through popular culture, with its emphasis on individualism, rebellion, and resistance. 